\title{
KAJIAN KEARIFAN LOKAL (LOCAL WISDOM) BUDIDAYA PADI (Studi Kasus Di Desa Sadar Kecamatan Tellu Limpoe Kabupaten Bone)
}

\section{Oleh}

\author{
Irmayani $^{1}$, Abby Azwaliza Binti Larola ${ }^{2}$, dan Yusradi ${ }^{3}$
}

Email: irmaumpar@yahoo.co.id,biazwaliza@gmai.com,yusry_ady@yahoo.co.id

${ }^{1,3)}$ Dosen Program Studi Agribisnis, Fakultas Pertanian, Peternakan dan Perikanan,

2) Mahasiswa Program Studi Agribisnis, Fakultas Pertanian, Peternakan dan Perikanan, Universitas Muhammadiyah Parepare

\begin{abstract}
Sadar village is one of the areas that still maintains the customs and habits carried out by their ancestors, one of which is during rice cultivation activities. Maintaining the rituals left by their ancestors is one way of appreciating the legacy that was given to them, apart from that, they also believe that something bad will happen to their society when they don't practice those habits. Globalization and the technological developments can have an impact on reducing the existing customs in Indonesia, therefore the purpose of this reseacrh is to determine the actions of rice cultivation in terms of local wisdom in village of Sadar.

The type of this research is descriptive which using a qualitative approach. Data collection techniques are (a) participant observation (b) in-depth interviews (c) documentation. Meanwhile, data analysis techniques use Miles and Huberman and data Triangulation.

Based on the result of this reseacrh, there were several customs and habits carried out by the Sadar village community in rice cultivation that is masappo wanua, mattudangtudang which is an activity before seeding and as for ma'doja bine at the of seeding. Macera taneng activities is while maintenance and mabatte, ma'sangki, ma'lempa, ma'tonase are harvest and postharvest activities.
\end{abstract}

Keywords: Rice cultivation, Local Wisdom, Rice farmers

\begin{abstract}
ABSTRAK
Desa Sadar merupakan salah satu daerah yang masih mempertahankan adat-istiadat serta kebiasaan yang dilakukan oleh para leluhur mereka salah satunya adalah kegiatan budidaya padi. Mempertahankan ritual yang ditinggal oleh nenek moyang mereka merupakan salah satu cara dalam menghargai peninggalan yang diberikan kepada mereka, selain daripada itu, mereka juga percaya bahwa akan ada sesuatu yang buruk terjadi pada masyarakat mereka ketika mereka tidak melakukan kebiasaan tersebut. Globalisasi dan juga perkembangan teknologi dapat berdampak terhadap berkurangnya adat-istiadat yang ada di Indonesia maka adapun tujuan penelitian ini adalah untuk mengetahu tindakan budidaya padi ditinjau dari kearifan lokal yang ada di Desa Sadar. Jenis penelitian yang digunakan adalah deskriptif dengan menggunakan pendekatan kualitatif. Teknik pengumpulan data yaitu (a) observasi partisipan (b) wawancara mendalam (c) dokumentasi. Sedangkan untuk teknik analisi datanya menggunakan analisis data Miles dan Huberman dan juga Triangulasi data.

Berdasarkan hasil penelitian bahwa terdapat beberapa tindakan adat-istiadat dan kebiasaan yang dilakukan masyarakat Desa Sadar dalam budidaya padi yaitu, masappo wanua, mattudang-tudang yang merupakan kegiatan sebelum pembenihan. Adapun
\end{abstract}


ma'doja bine pada saat pembenihan, ma'cera taneng kegiatan saat pemeliharaan dan ma'batte, ma 'sangki, ma'lempa, ma'tonase adalah kegiatan panen dan pascapanen.

Kata Kunci: Budidaya padi, Kearifan lokal, Petani padi

\section{A. PENDAHULUAN}

Masyarakat yang masih menjalankan kebiasaan yang dilakukan oleh leluhur terdahulu mereka, menganggap bahwa apa yang mereka lakukan adalah sesuatu yang sangat penting yang berdampak pada kehidupan sehari-hari mereka. Tidak hanya itu, menjaga apa yang telah diwariskan leluhur mereka merupakan salah satu cara untuk menghargai orang-orang terdahulu. Seperti halnya masyarakat yang berada di Desa Sadar, Kecamatan Tellulimpoe, Kabupaten Bone. Masyarakat di Desa Sadar masih berpegang teguh pada tradisi yang telah diberikan oleh para leluhur mereka.

Desa Sadar yang termasuk dalam Kabupaten Bone merupakan sebuah desa dimana mayoritas masyarakatnya bermata pencahrian di bidang pertanian, komoditi utama mereka adalah cengkeh, kakao dan juga padi. Selain masyarakat tani, penduduk desa Sadar juga merupakan masyarakat yang masih memegang teguh ada-istiadat dan budaya yang ditinggalkan oleh para leluhur mereka yang diwariskan secara turun temurun dari generasi ke generasi hingga pada saat ini. Contoh adat istiadat dan kebudayaan yang masih mereka pegang teguh adalah ketika masyarakat desa Sadar ingin melakukan pesta pernikahan maka tidak akan bisa melakukannya melainkan ada waktuwaktu tertentu yang telah di tetapkan dan sampai saat ini masih mereka jalankan. Contoh ini merupakan bukti bahwa masyarakat desa Sadar masih memegang teguh adat-istiadat dan kebudayaan leluhur mereka.

Padi merupakan salah satu sumber utama mata pencahrian masyarakat desa Sadar, maka dalam mengelola budidaya padi mereka juga masih memegang teguh adat-istiadat dan kebudayaan yang diwariskan oleh leluhur mereka. Hal ini bisa dilihat dengan cara bagaimana mereka dari tahapan sebelum penyiapan lahan hingga panen masih menggunakan kearifan lokal (local wisdom) yang diperoleh melalui pembelajaran langsung maupun tidak langsung seperti pada tradisi ataupun melalui komunikasi verbal.

secara umum dapat dipahami bahwa kearifan lokal adalah gagasan gagasan setempat (lokal) yang bersifat bijaksana, penuh kearifan, bernilai baik yang tertanam dan diikuti oleh anggota-anggota masyarakatnya (Sartini, 2004; 
Muhammad Dokhi dkk, 2016). Tempat tinggal yang didiami setiap kelompok masyarakat tertentu pastinya berbeda satu dengan yang lainnya. Hal tersebut dikarenakan wilayah geografis yang berbeda. Perbedaan tersebut pula kemudian memunculkan gaya kehidupan yang berbeda yang di sesuaikan dengan kondisi wilayahnya. Terkadang dalam proses beradaptasi dengan gaya kehidupan yang sesuai dengan keadaan geografis bisa memicu masyarakat setempat belajar dengan hal-hal baru yang akhirnya hal ini di sebut dengan pengetahuan lokal masyarakat setempat karena hal tersebut didapatkan di tempat tinggal mereka yang akhirnya di implementasikan pada kehidupan seharihari yang menjadi kearifan lokal (local wisdom) karena di dalam nya terdapat kebijaksanaan yang bersifat lokal atau hanya berlaku di tempat mereka. Sibarani dalam Hasman dan Iskandar (2019) mengatakan bahwa "local wisdom is wisdom or original knowledge of a community derived from the value of cultural traditions ancestor to regulate social order". Selain itu, Hasman dan Iskandar (2019) juga mengemukankan “it can be said that local wisdom is formed as a local culture excellence associated with geographical conditions in the broad sense".

Penelitian terdahulu yang dilakukan oleh Fatmawati P. yang berjudul pengetahuan lokal petani dalam tradisi bercocok tanam padi oleh masyarakat Tapango Polewali Mandar pada tahun 2019 membahas tentang kebiasaan yang dilakukan masyarakat Tapango dalam bercocok tanam, dimana kebiasaankebiasaan ritual yang dilakukan mereka bersumber dari para leluhur mereka yang didapatkan secara verbal maupun tidak. Kebiasaan-kebiasaan itu pada akhirnya tergeserkan oleh teknologi modern yang berkembang pesat di desa Tapango. Perubahan dan pergeseran yang dialami kemudian berdampak pada sistem nilai yang terkandung. Penelitian ini memberikan gambaran nyata terhadap dampak teknologi tersebut pada pengetahuan lokal bercocok tanam yang ada di Desa Tapango sehingga pada penelitian yang dilakukan dalam penelitian ini yang mengkaji tentang kearifan lokal budidaya padi di Desa Sadar didapati bahwa kearifan lokal yang ada di Desa Sadar bukan hanya sebuah kebiasaan yang mereka ikuti dari leluhur mereka tetapi terdapat keyakinan yang kuat,kebijaksanaan, dan makna yang 
terkandung di setiap proses yang dilakukan oleh masyarkat Desa Sadar.

Tanaman padi merupakan salah satu tanaman yang sangat penting bagi masyarakat Indonesia, tanaman padi yang nantinya akan ketika sudah diolah dan menjadi nasi merupakan makanan pokok bagi mayoritas masyarakat di Indonesia. Perlakuan masyarakat Desa Sadar terhadap budidaya padi yang berbasis pada kearifan lokal merupakan suatu fenomena sosial dimana terjadinya proses pembelajaran bagi masyarakat melalui generasi sebelumnya atau mencontoh perilaku mereka dalam budidaya padi yang kemudian pembelajaran tersebut membentuk sikap dan perilaku petani itu sendiri. Hal ini didukung oleh teori dari Max Weber dalam Umanailo, 2019 yang mengatakan bahwa individu melakukan suatu tindakan berdasarkan pengalaman, persepsi, pemahaman atas suatu objek stimulus atau situasi tertentu. Weber juga berpendapat bahwa sesuatu tidak akan dikatakan tindakan sosial jika individu tersebut tidak memiliki tujuan dalam melakukan tindakan tersebut. Teori ini juga didukung oleh teori Graybiel yang mengatakan bahwa manusia membentuk kebiasaan ketika mereka mengulang perilaku yang berorientasi pada tujuan dalam konteks berulang: dengan pengulangan yang terus menerus dan konsisten, urutan perilaku yang dipelajari akan menjadi potongan perilaku tunggal yang akan dieksekusi secara otomatis secara keseluruhan setelah dipicu oleh isyarat kontekstual.

Praktek budidaya padi yang dilakukan oleh masyarakat desa Sadar terdapat beberapa kearifan lokal yang mereka terapkan. Dari tahap sebelum tahapan persiapan benih mereka akan melakukan ritual yang disebut dengan masappo wanua yang bertujuan untuk memagari kampung dan menutup kegiatan selain dari budidaya padi. Setelah itu, diikuti dengan kearifan lokal mattudan-tudang, maddoja bine, maccera taneng, mabbura ase, massangki, malempa dan diakhiri dengan mattonase, dimana dalam kegiatan mattonase tersebut merupakan tanda syukur masyarakat desa Sadar karena telah panen. Tindakan yang mereka lakukan bukan hanya suatu tindakan biasa, tetapi juga mengandung nila-nilai kepercayaan yang kemudian membentuk pola kehidupan masyarakat petani di Desa Sadar.

Perkembangan teknologi telah berkembang pesat di Indonesia dan ilmu mengenai pertanian modern dengan sangat mudah di dapatkan tetapi masih 
banyak petani yang masih menggunakan kearifan lokal (local wisdom) dalam budidaya padi. Alasan dari dipertahankan kearifan lokal (local wisdom) dalam budidaya padi memiliki berbagai alasan bagi para petani yang masih menggunakannya. Sebagian masyarakat petani menganggap bahwa kearifan lokal (local wisdom) merupakan sesuatu yang bisa mengakrabkan masyarakatnya. Sedangkan sebagian masyarakat lainnya yang masih menggunakannya percaya bahwa ketika hal tersebut ditinggalkan maka akan ada musibah yang menimpa masyarakatnya. Meskipun memiliki alasan yang berbeda dalam mempertahankannya, kearifan lokal (local wisdom) merupakan salah satu budaya Indonesia yang penting untuk dipertahankan. Selain itu, kearifan lokal (local wisdom) juga merupakan salah satu penghubung para leluhur terdahulu dan juga generasi yang ada pada saat ini. Penelitian

Penelitian terdahulu mengenai kearifan lokal (local wisdom) dalam budidaya padi membuktikan bahwa masih banyak daerah di Indonesia yang masih menjalankan adat-istiadat para leluhurnya. Hal ini merupakan salah satu langkah yang tepat untuk bisa mempertahankan budaya itu sendiri karena tidak menutup kemungkinan budaya yang ada akan semakin berkurang akibat dampak dari globalisasi dan juga perkembangan dari teknologi itu sendiri.

Kearifan sebagai salah satu warisan nenek moyang yang harus dilestarikan karena menjadi salah satu kekayaan budaya yang ada di Indonesia. Perkembangan teknologi dan juga dampak globalisasi semakin lama semakin mengerus keberadaan kearifan lokal itu sendiri. Melakukan penelitian terhadap kearifan lokal dalam budidaya padi yang ada di Desa Sadar Kecamatan Tellu Limpoe Kabupaten Bone merupakan salah satu cara untuk mengenal dan mengeksplor kearifan lokal sehingga dapat memberikan informasi mengenai budaya lokal yang ada di Desa Sadar dan juga sebagai salah satu upaya dalam mempertahnakan budaya dalam tulisan ilmiah.

Berdasarkan penjelasan yang telah diatas, maka rumusan permasalahannya adalah bagaimana tindakan budaya padi ditinjau dari segi kearifan lokal yang ada di Desa Sadar.

Adapun tujuan dari Penelitian ini adalah untuk mengetahui tindakan budidaya padi ditinjau dari kearifan lokal yang ada di Desa Sadarr. 


\section{B. METODE PENELITIAN}

Jenis penelitian yang digunakan dalam penelitian ini adalah deskriptif dengan menggunakan pendekatan kualitatif. Sugiyono dalam Direktorat Tenaga Kerja (2008) mengatakan bahwa penelitian kualitatif ditujukan untuk memahami fenomena-fenomena sosial dari sudut pandang pastisipan. Pemlihan informan awal pada penelitian in dipilih secara sengaja (purposive) yaitu informan yang dianggap mengetahui banyak kondisi desa yang diteliti sesuai dengan tujuan penelitian dengan menggunakan teknik snowball sampling. Hal pertama yang dilakukan yaitu mencari key informant (informan kunci). Informan kunci yang diambil pada penelitian in adalah ketua adat/tokoh adat yang mengetahui budaya yang ada di desa Sadar dan terlibat

langsung dalam pelaksanaannya.

Sumber data pada penelitian ini ada dua yaitu (1) data primer yang diperoleh oleh peneliti dalam keterlibatannya dilokasi penelitian yang dilihat dari gesture (bahasa tubuh/sikap) informan dan wawancara mendalam. (2) data sekunder yaitu data yang sudah dikumpul terlebih dahulu atau dihasilkan oleh orang lain (Victor Oluwatosin Ajayi, 2017) yang pada penelitian ini didapat dari teori dan juga kajian pustaka yang dirujuk. Adapun teknik pengumpulan data pada penelitian ini adalah (1) observasi partisipan dimana peneliti terlibat langsung dalam proses kearifan lokal yang dilaksanakan. Setelah melakukan pengumpulan data, selanjutnya dilakukan teknik analisis data dengan cara membuat kategorisasi atau mengelompokkan serta menyortir data-data yang diperoleh secara tersistem sesuai dengan kepentingan penelitian. Setelah melakukan pengelompokan data, lalu dilanjutkan dengan tahap reduksi data. Tahap terakhir yang dilakukan adalah membuat pernyataan-pernyataan berdasarkan hasil interpretasi data dan menarik sebuah kesimpulan.

\section{HASIL DAN PEMBAHASAN}

\section{Identifikasi Kearifan Lokal}

Terhadap Kegiatan Budidaya Padi di Desa Sadar

Kegiatan budidaya padi yang dilakukan oleh petani di Desa Sadar merupakan suatu penerapan dari pengetahuan khusus yang bersumber dari hasil pembelajaran petani-petani terdahulu yang merumuskan suatu teknik budidaya padi berdasarkan dengan kondisi geografis dan ekologis di Desa Sadar yang sampai saat ini masih diterapkan oleh masyarkat setempat. 
Sistem pengetahuan tersebut tidak hanya mengenai cara atau teknik dalam budidaya padi tetapi juga terdapat nilainilai kearifan atau kebijaksanaan lokal yang terkandung didalamnya yang bermanfaat tidak hanya pada produktivitas padi tetapi juga dari nilai spiritual bagi masyarakat yang menerapkannya. Sistem pengetahuan tersebut tercermin dalam ritual dan tradisi-tradisi kebiasaan yang dilakukan oleh petani setempat dari sebelum pembenihan sampai dengan pasca panen. Didalam ritual tersebutlah terkandung nilai-nilai kearifan lokal atau kebijaksaan setempat yang artinya nilai-nilai kearifan tersebut hanya ada dimasyarkat tersebut dan hanya diterapkan oleh mereka yang ketika ritual dan tradisi-tradisi kebiasaan tersebut tidak dilakukan maka petani menyakini bahwa akan berakbiat buruk bagi produktivitas padi mereka seperti penurunan hasil produksi dan juga gagal panen. Selain itu, mereka juga mempercayai bahwa akan ada sesuatu buruk yang terjadi dalam masyarakat mereka.

Ada 9 tahapan tradisi dan kebiasaan-kebiasaan yang dilakukan petani dalam melaksanakan kegiatan budidaya di Desa Sadar. Pada saat sebelum melakukan pembenihan, petani akan melakukan kegiatan ma'sappo wanua dan juga ma'tudang-tudang. Kegiatan ma 'sappo wanua dapat diartikan sebagai kegiatan memagari kampung. Naba (75 tahun) menjelaskan bahwa masyarakat Desa Sadar akan berkumpul di rumah poko' (rumah utama untuk melakukan ritual dan adat kebiasaan) yang dinamakan ma'sappo wanua, kampung dipagari agar tidak ada hal-hal lain yang masuk ke dalam kampung tersebut dan hanya fokus ke pada budidaya padi. Dalam kegiataan ma'sappo wanua tersebut akan dilakukan tudang-sipulung yang ketika diterjemahkan maka sama halnya dengan bermusyawarah. Kegiatan ini dilakukan dalam rangka penentuan tanggal mereka akan mulai melakukan kegiatan budidaya padi. Metode yang digunakan dalam menentukan tanggal adalah dengan melihat bintang atau disebut dengan pananrang yang sudah ada sejak lama. Alasan petani masih menggunakan pananrang dalam budidaya padinya karena mereka merasa cocok dengan pertanian yang mereka lakukan, dalam arti bahwa apa yang mereka lakukan ini memberikan manfaat bagi mereka. Setelah penentuan tanggal, maka mereka akan mengantungkan daun lindrug (Aren) yang sudah dibentuk sesuai dengan 
kepercayaan mereka di batas-batas desa dan juga di rumah poko'. Hal ini dilakukan sebagai cara mengumumkan kepada masyarakat desa bahwa akan dimulai kegiatan Sangiang Serri (Padi) dan juga pemberitahuan bahwa masyarakat sudah tidak bisa melakukan kegiatan lain daripada kegiatan budidaya padi.

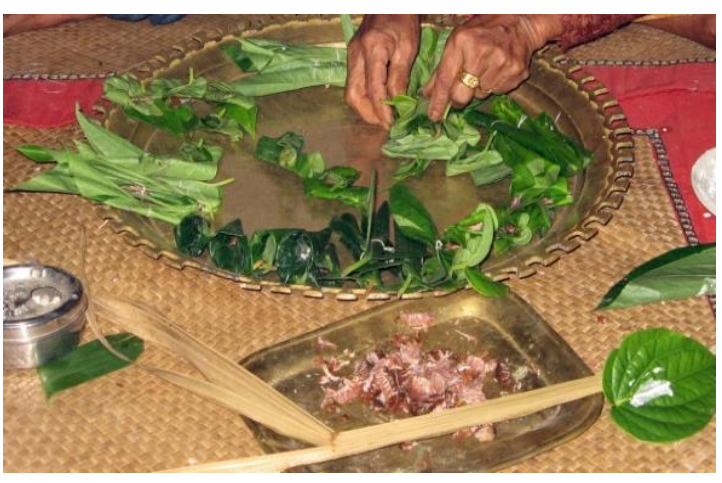

Gambar 1. Daun Sirih Yang Akan Digantungkan

Ma'tudang-tudang merupakan kegiatan yang dilakukan di sebuah tempat khusus yang memiliki sumber mata air karena petani Desa Sadar sangat menghargai dan menjunjung tinggi derajat air bagi kehidupan mereka karena air tidak hanya digunakan untuk manusia tetapi juga semua makhluk hidup termasuk padi. Kegiatan atau ritual yang dilakukan oleh petani di tempat khusus tersebut adalah membaca doa dan makan bersama dimana setiap kepala keluarga/rumah akan membawa ayam kampung yang sudah dimasak dirumah masing-masing. Selain itu, mereka juga memiliki ritual ma'genrang (memukul gendang dengan nada khusus). Kegiatan matudang-tudang tidak hanya sebagai sebuah rangkaian dalam tahapan budidaya padi tetapi juga suatu cara untuk memperkuat batin masyarakat dalam melakukan kegiatan budidaya padi dan juga meminta doa keberkahan agar panen mereka berhasil.

Selain itu, tindakan memukul gendang juga dianggap sebagai penyemangat karena bunyi-bunyiannya. Koentjaraningrat (1992) mengatakan bahwa sistem upacara yang dihadiri oleh masyarakat berarti dapat memancing bangkitnya emosi keagamaan pada tiaptiap kelompok masyarakat (Kamaruddin, 2017).

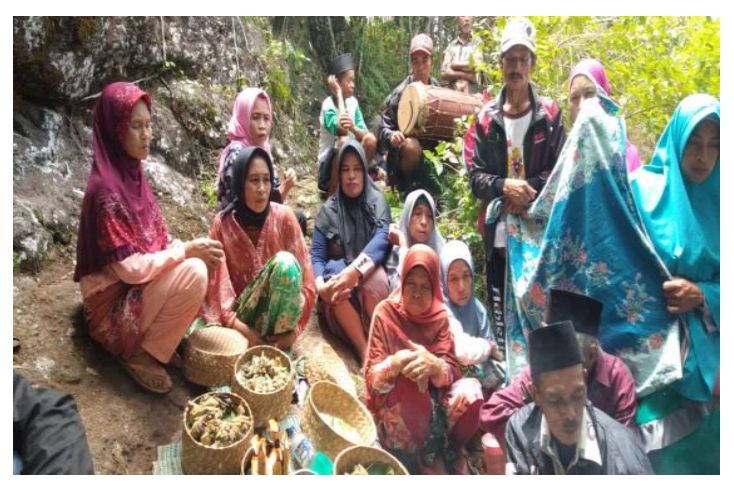

Gambar 2. Masyarakat yang berkumpul untuk pelaksanaan kegiatan ma'tudangtudang.

Apabila kegiatan matudang-tudang telah selesai dilakukan, maka petani akan menyiapkan lahan. Tidak ada tindakan 
khusus pada kegiatan ini. Petani menggunakan mesin traktor untuk menyiapkan tanahnya yang waktu pengerjaannya tergantung dari luas lahan yang dimilki petani. Setelah menyiapkan lahan, maka petani akan mulai melakukan pembenihan. Benih yang digunakan merupakan benih yang sudah dipisahkan dari panen sebelumnya yang kemudian diambil yang berisi dengan menggunakan alat yang disebut pa'tapi. Pemisahan gabah ini dilakukan untuk mendapatkan hasil panen yang baik. Pemilihan benih ini diumpakan sebagai seorang ibu yang melahirkan anak-anaknya lebih baik dari dirinya karena padi diidentikkan sebagai ibu sebagai jelmaan dari Shang Yang Seri sehinnga diperlakukan dengan istimewa sebagaimana kita mengistimewakan seorang ibu. Irmayani (2016). Pembenihan dilakukan dengan cara merendam gabah yang sudah disimpan untuk menjadi bibit selama 1 atau 2 malam dibawah rumah, setelah itu padi yang sudah drendam akan dimasukkan ke dalam karung dan dinaikkan ke atas rumah dan di opung selama 2 s/d 3 malam. Opung adalah cara untuk menghidupkan padi yang sudah direndam untuk menjadi benih. Apabila benih sudah di opung maka kepala keluarga di rumah tersebut akan menjalankan ritual madoja bine yang akan dilakukan oleh kepala keluarga, mereka akan bergadang hingga pagi dengan memakan sokko yang terbuat dari beras ketan dan juga dimakan bersama dengan gula. Sokko memiliki filosofi yang diharapkan agar keluarga dan masyarakat dapat menjaga keuntuhan dan persatuan dalam menjalankan segala aktivitas karena sokko yang terbuat dari ketan memiliki tekstur lengket dan susah untuk lepas antara satu dengan lainnya. Mereka juga menyanyikan lagu khusus yang dipercayai bisa berpengaruh kepada kualitas padi. Perlakuan petani yang menyanyikan lagu sebagai rasionalitas menandakan bahwa ada emosi yang disampaikan lewat lagu dan juga sebagai doa untuk hasil dari budidaya padi mereka. Pada keesokan harinya, benih tersebut akan dibawa ke sawah untuk ditabur pada sekitar jam 07.00-09.00 pagi.

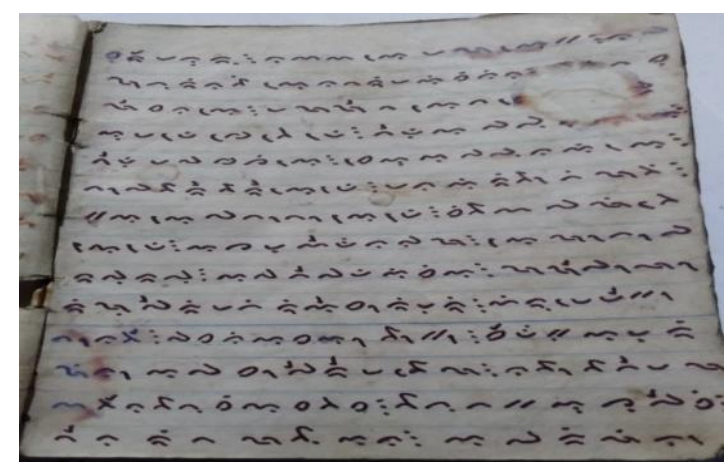

Gambar 3. Naskah nyanyian khusus dalam ma'doja bine

Benih yang sudah ditabur di sawah setelah kurang lebih 25 hari, benih 
tersebut akan dicabut kembali yang disitlahkan dengan magebu' oleh warga setempat kemudian ditanami di sawah dengan memberi jarak yang sudah di tentukan oleh pemilk sawah. Kegiatan ini akan dilakukan secara sibaliang atau saling membantu oleh masyarkat setempat yang terlebih dahulu sudah dimulai tanam oleh pemilik sawah sebagai orang yang berhak atas sawah tersebut. Kehidupan gotong-royong merupakan persekutuan yang mempunyai kelonggaran struktur didalamnya bagi masyarakat petani (Wolf; Meta Rolitia dkk, 2016). Salah satu mekanisme tradisional dalam mempertahankan hidup adalah kehidupan masyarakat yang di landasi oleh relasi sosial (Meta Rolitia et al., 2016).

Apabila selesai melakukan penanaman maka petani akan segera memupuknya dan juga memotong ayam kampung yang nantinya akan dibawah ke sawah untuk dimakan sebagai tanda syukur telah selesai melaksanakan kegiatan penanaman padi yang disebut dengan kegiatan macera taneng. Ketika padi yang sudah ditanam akan mulai berbuah yang disebut dengan padi mangideng oleh warga setempat maka mereka akan memotong ayam kampung dan membuat sokko yang nantinya akan dibacang (didoakan) lalu dibawah ke sawah untuk dimakan oleh keluarga pemilik sawah. Hal ini dilakukan sebagai wujud syukur kepada yang Maha Kuasa karena padi mereka segera akan berbuah. Dalam hal pemeliharaan padi untuk menghindari dari terserang penyakit dan hama, selain menggunakan pestisida, petani akan melakukan tahapan mabura ase, dimana mereka akan menggunakan daun sirih (Piper betle L.) yang sudah dihaluskan akan dicampur dengan minyak kelapa yang kemudian akan diberikan pada padi. Irmayani dalam Wahyuni (2018) mengungkapkan bahwa keberhasilan dari pemelihraan padi adalah ketika petani membangun kedekatan dengan tanaman itu sendiri dengan cara kontrol dan dan komunikasi yang disertai dengan pengharapan-pengharapan yang baik untuk keberhasilan tanamannya hingga panen.

Sebelum melakukan panen, terdapat suatu tradisi yang dilakukan oleh para petani yang disebut dengan tradisi mabatte (menumbuk padi yang muda). Hal ini dilakukan oleh petani sebagai tanda syukur dan juga sebagai pertanda karena sebentar lagi mereka akan melakukan panen. Padi akan ditumbuk dengan tidak terlalu halus lalu disangrai kemudian dibaca doakan dan dimakan bersama-sama. Padi yang sudah tua akan 
dipanen oleh petani yang didahului dengan tradisi madumpu, dimana gula merah akan dibakar dan juga ota (daun sirih) yang sudah dilipat akan disimpan di samping duтрu (gula merah yang dibakar) yang asap dari gula merah akan di berikan (diasap-asapkan) pada padi di salah satu sudut sawah sebagai tanda untuk mappula massangki (memulai panen). Asap yang digunakan petani dipercaya sebagai tanda untuk meminta izin kepada puang'e (Yang Maha Kuasa) untuk memulai kegiatan panen. Keesokan harinya, pemilik sawah akan memberitahu sanak-saudara mereka bahwa mereka telah melakukan panen, dimana nantinya sanak-saudara mereka akan ikut membantu dan juga di ikuti oleh warga masyarakat lainnya.

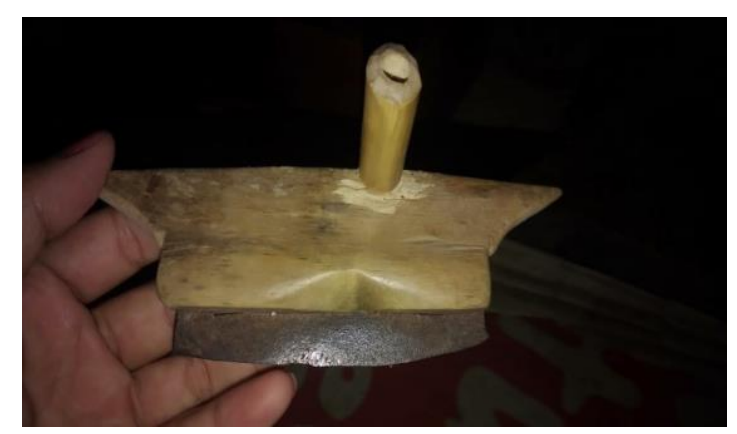

Gambar 4. Alat pemotong padi untuk

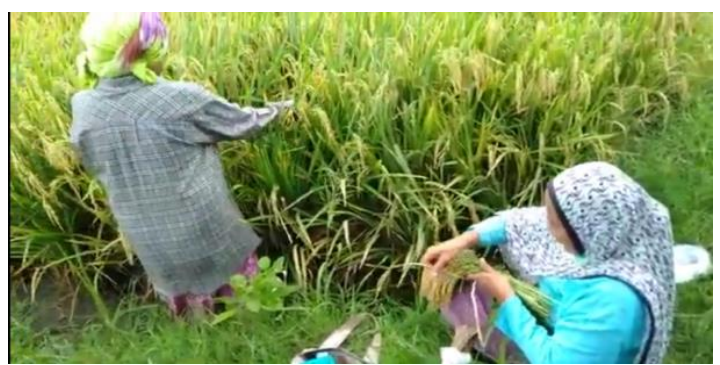

Gambar 5. Kegiatan memulai panen
Padi atau gabah yang sudah dipanen tidak langsung dibawah ke bola pokok (rumah utama), petani akan membuat lawang yang terbuat dari tenda. Fungsi lawang ini adalah sebagai tempat penyimpanan gabah karena gabah akan dijemur terlebih dahulu di sawah selama kurang lebih satu minggu atau sampai air digabah akan kering. Di lawang tersebut juga akan di berikan ota (daun sirih yang sudah di lipat) yang diartikan oleh petani di Desa Sadar sebagai sesuatu untuk mappasewa ada (untuk komunikasi) sebelum padi atau gabah akan di bawah ke bola pokok (rumah utama) yang disebut dengan petani setempat dengan malempa. Malempa akan dilakukan ketika padi atau gabah yang disimpan dii lawang (tenda) sudah kering, kegiatan ini akan dilakukan secara gotong-royong dimana sanak-saudara dan warga akan membantu membawanya ke bola pokok. Menjemur gabah sebelum dibawah kerumah dianggap sebagai bagian dari adat oleh petani di Desa Sadar tetapi jika kegiatan atau tindakan mereka ditinjau dalam segi rasionalitas maka kegiatan menjemur padi dimaknai untuk meringankan petani dalam proses membawanya sampai ke tempat tujuan.

Syukuran akhir akan dilakukan pada saat semua warga telah selesai panen 
yaitu sekitar bulan September yang disebut dengan mattonase. Syukuran ini hanya dapat dilakukan ketika semua petani sudah selesai melaksanakan panen yaitu sekitar bulan September. Pada syukuran ini, karena setiap keluarga yang sudah melaksanakan panen menyimpan padi atau gabah mereka di bola pokok, maka setiap setiap keluarga masingmasing akan melaksanakan mattonase. Mereka akan membuat sokko dan juga memotong ayam yang nantinya akan dibaca terlebih dulu oleh tokoh adat masyarakat lalu dimakan bersama dengan warga yang juga datang meraimakan. Doa yang disampaikan merupakan doa sipulung ataupun doa selamat tergantung dari kehendak petani. Doa sipulung diartikan sebagai doa kebaikan untuk semua anggota keluarga sedangkan doa selamatan diartikan untuk memohon keselamatan bagi petan sampai ke panen berikutnya. Mattonase ini merupakan syukuran akhir yang dilakukan oleh petani karena sudah menyelesakan kegiatan sini siri (padi) dari awal hingga akhir yang dilakukan dengan rasa tanggungjawab. Keluarga yang sudah melaukan kegiatan masyarakat ini sudah bisa melakukan kegiatan lainnya (misalkan mengadakan pesta pernikahan dan memotong hewan untuk dimakan), yang berarti mereka sudah terlepas dari kegiatan sini siri.

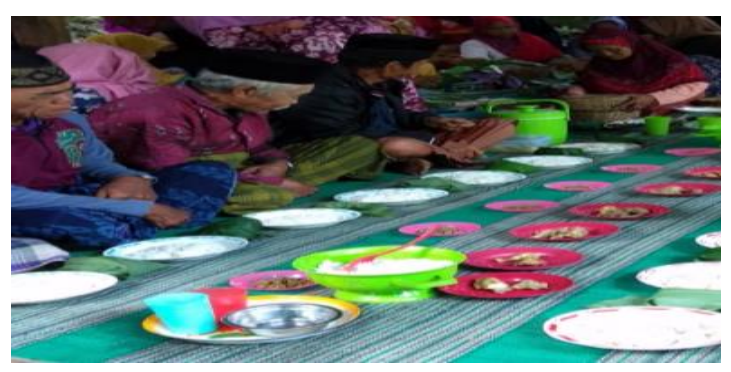

Gambar 6. Kegiatan baca doa yang dilakukan petani

\section{Kearifan Lokal Sebagai Kekayaan Budaya}

Penelitian ini sejalan dengan pemikiran dari Weber yang mengatakan bahwa individu melakukan suatu tindakan berdasarkan pengalaman, persepsi, pemahaman atas suatu objek stimulus atau situasi tertentu. Weber juga berpendapat bahwa sesuatu tidak akan dikatakan tindakan sosial jika individu tersebut tidak memiliki tujuan dalam melakukan tindakan tersebut (Umanailo, 2019

Tindakan dari tahapan budidaya padi berdasarkan dari kearifan lokal yang dilakukan oleh masyarakat di Desa merupakan satu budaya yang harus dijaga, selain dari karena tindakan ini merupakan suatu kekayaan budaya yang dimiliki oleh masyarakat Desa Sadar khususnya, budaya ini juga merupakan sesuatu yang bisa merekatkan hubungan antara sesama masyarakat nya karena nilai-nilai lokal 
yang ada di dalam setiap tahapan adatistiadat dan kebiasaan yang dilakukan seperti misalnya nilai sibalian atau gotong-royong, nilai kebersamaan, tanggungjawab dan juga terdapat nilai spiritual di dalamnya. Kearifan lokal juga harus dijaga agar nilai-nilai lokal yang ada di Desa Sadar tidak hilang karena akan berdampak pada kehidupan sosial masyarakatnya, apabila nilai-nilai lokal yang ada tidak dijaga maka nilai kebersamaan masyarakat sudah tidak akan terlihat lagi. Selain daripada itu, kearifan lokal juga merupakan suatu cara dalam melestarikan lingkungan. Dalam kegiatan kearifan lokal akan terdapat nilai-nilai kebijakan dalam mengelola alam, masyarakat merasa bahwa alam adalah bagian dari mereka sehingga mereka harus menjaga nya dnegan baik.

Upaya dalam menjaga keberlanjutan kearifan lokal yang ada di Desa Sadar tidak hanya di titik beratkan kepada masyarakat bagaimana mengajarkan dan menanamkan nilai-nilai lokal kepada generasi berikutnya tetapi juga pemeritah memiliki peran yang juga sangat penting dalam menjaga kearifan lokal. Kebijakankebijakan yang dibuat pemerintah haruslah sejalan dengan nilai-nilai lokal yang ada di Desa Sadar. Salah satu cara yang dapat dilakukan oleh pemerintah setempat adalah mengagas pertanian organik.

Pertanian organik yang dimaksud adalah, budidaya padi tanpa menggunakan pestisida maupun pupuk kimiawi. Hal ini dapat dilakukan dengan cara melakukan penyuluhan terhadap pembuatan pupuk dan pestisida nabati yang dapat di produksi sendiri oleh petani setempat. Hasil pertanian yang dihasilkan oleh petani nantinya dapat dijual dengan harga yang lebih dibandingkan harga sebelumnya. Pertanian organik ini tidak hanya bermanfaat bagi petani karena dapat meningkatkan harga jualnya tetapi dengan hal ini, Desa Sadar dapat dijadikan sebagai objek wisata pertanian organik berbasis pada kearifan lokal yang didalamnya terdapat nilai-nilai lokal masyarakat desa Sadar dan memberikan kesempatan yang luas untuk keberlangsungan kearifan lokal ini.

\section{KESIMPULAN}

Kearifan lokal yang dalam budidaya padi yang dilakukan oleh masyarakat Desa Sadar merupakan salah satu kekayaan budaya yang harus dilestarikan. Pelestarian budaya ini tidak hanya dititik berat kepada petani dan keluarga tetapi bagaimana pemerintah juga mengambil peran penting dan salah satu upaya yang dapat dilakukan oleh pemerintah adalah 
mengagas pertanian organik yang berbasis

kearifan lokal yang juga dapat dijadikan sebagai daya tarik wisata.

\section{DAFTAR PUSTAKA}

Ajayi, V. O. (2017). Primary Sources of Data and Secondary Sources of Data. September, 1-6. https://doi.org/10.13140/RG.2.2.242 92.68481

Buru, U. I. (2019). Max weber.October.ht tps://doi.org/10.31219/osf.io/ep7n

Hasyim, H., \& Muda, I. (2019). Effects Of Local Wisdom In The Form of Planting Prayer In The Regional Development On Rice Paddy Farmers Revenue In Indonesia. 8(06), 90-98.

Irmayani. (2016). Spiritualitas, Rasionalitas, Dan Keberlanjutan Pertanian (Studi Fenomenologi Komunitas Petani di Desa BoneBone Kabupaten Enrekang). Sekolah Pascasarjana Universitas Hasanuddin Makassar.

Jainuddin, J., Silalong, E. S., \& Syamsuddin, A. (2020). Eksplorasi Etnomatematika pada Ukiran Toraja. Delta-Pi: Jurnal Matematika dan Pendidikan Matematika, 9(2).

Kamaruddin. (2017). BARZANJI (Suatu Tradisi Masyarakat Bugis Di Desa Appanang Ke. Liliriaja Kab.
Soppeng). Departemen Antropologi Sosial Fakultas llmu Sosial Dan Ilmu Politik Universitas Hasanuddin.

Kemendikbud. (2016). Analisis Kearifan Lokal Ditinjau dari Keragaman Budaya. Pusat Data Dan Statistik Pendidikan Dan Kebudayaan (PDSPK),167. http://publikasi.data.k emdikbud.go.id/uploadDir/isi_F9D2 8- 4D62-BCAE-E89FEB2D2EDB_. pdf

P, F. (2019). Pengetahuan Lokal Petani Dalam Tradisi Bercocok Tanam Padi Oleh Masyarakat Tapango Di Polewali Mandar. Walasuji: Jurnal Sejarah Dan Budaya, 10(1), 85 95.ht tps://doi.org/10.36869/wjsb.v10i1

Rolitia, M., Achdiani, Y., \& Eridiana, W. (2016). Nilai Gotong Royong Untuk Memperkuat Solidaritas Dalam KehidupanMasyarakatKampung Naga. Sosietas,6(1).https://doi.org/1 0.17509/sosietas.v871

Surya Dharma, MPA., P. . (2008). Pendekatan, jenis, dan metode penelitian pendidikan. Vol, I. (2015). LOCAL WISDOM OF FARMERS IN MEETING. 1(1), 53-60.

Wahyuni. 2018. Kearifan Lokal Terhadap Kegiatan Usahatani Padi Di Desa Rossoan Kecamatan Enrekang Kabupaten Enrekang. Fakultas Pertanian, Peternakan dan Perikanan. Universitas Muhammadiyah Parepare. 